\title{
Prevalence and Predictors of Syphilis in Female Sex Workers in Eastern China: Findings from Six Consecutive Cross-Sectional Surveys
}

This article was published in the following Dove Press journal: Journal of Multidisciplinary Healthcare

\author{
Tiansheng Xie $\mathbb{D}^{1,2}$ \\ Guohua Wang ${ }^{3}$ \\ Qiang Sun ${ }^{3}$
}

'Zhejiang Sino-German Institute of Life Science and Healthcare, School of Biological and Chemical Engineering, Zhejiang University of Science and Technology, Hangzhou, Zhejiang, 310023, People's Republic of China; ${ }^{2}$ State Key Laboratory for Diagnosis and Treatment of Infectious Diseases, The First Affiliated Hospital of Zhejiang University, School of Medicine, Zhejiang University, Hangzhou, Zhejiang, 310003, People's Republic of China; ${ }^{3}$ Tongxiang Center for Disease Prevention and Control, Jiaxing, Zhejiang, 314500, People's Republic of China
Correspondence: Tiansheng Xie Zhejiang Sino-German Institute of Life Science and Healthcare, School of Biological and Chemical Engineering, Zhejiang University of Science and Technology, 3 I 8 Liuhe Road, Hangzhou, Zhejiang Province, 310023, People's

Republic of China

Tel +8657l 86021350

Email tianshengxie@zust.edu.cn
Purpose: Female sex workers play an important role in transmitting HIV and syphilis from high-risk groups to the general population. However, epidemic trends and risk factors for syphilis in Chinese female sex workers (FSWs) remain unclear.

Methods: Using convenient sampling methods, 2482 FSWs were interviewed and tested for syphilis from 2014 to 2019, all of them were divided into two groups of high-grade FSWs and low-grade FSWs according to service solicited and clients price there were. Demographic data were collected and logistic regression analysis was used to identify risk factors for syphilis.

Results: $43.67 \%$ of participants have received free condoms, $76.15 \%$ of them engaged in peer education of the 2482 FSWs tested for syphilis, 107 (4.31\%) were positive. The prevalence of syphilis in high-grade FSWs was significantly lower than that in low-grade FSWs (3.14\% and $5.62 \%$, respectively). The overall prevalence of syphilis increased from $3.19 \%$ to $4.47 \%$. The percentage of FSWs received free condoms and engaged in peer education increased significantly. With upgraded awareness of syphilis, the number of FSWs having protected sex also increased significantly. It is also found that low-grade female sex workers are at greater risk of syphilis than those high-grade ones (odds ratio $(\mathrm{OR})=1.76,95 \%$ CI 1.18-2.63, $\mathrm{p}<0.05)$.

Conclusion: Great awareness of syphilis and the increased utilization of condom did not reduce the prevalence of syphilis, especially in low-grade FSWs group. More effective integrated interventions should be developed for such populations.

Keywords: education, risk reduction, health promotion, risk behaviours, syphilis

\section{Introduction}

Syphilis is an infectious disease caused by the spirochete Treponema pallidum. Many countries have committed to reducing the rates of adult syphilis, and to eliminating congenital syphilis. ${ }^{1}$ The World Health Organization (WHO) "Global Health Sector Strategy on Sexually Transmitted Infections (STIs) 2016-2021" has two syphilis-related targets. ${ }^{2,3}$ Between 2012 and 2016, the prevalence of probable active syphilis in women decreased in 54 (41\%) of 132 eligible countries; this decrease was substantive in 5 countries. ${ }^{4}$ Still the need for increasing investments in national syphilis surveillance and control efforts is to be met.

Syphilis is also common in China as the third most common infectious disease. ${ }^{5,6}$ The average annual increase in the incidence of syphilis was as high as $16.3 \%$ between 2004 and $2013,^{7}$ which was mainly due to a large commercial sex industry with 
approximately 10 million female sex workers (FSWs). ${ }^{8}$ FSWs in China are hard to be reached by conventional health manage and intervention programs. ${ }^{9}$ In China, FSWs play an important role in the transmission of STIs from high-risk groups to the general population. ${ }^{10,11}$ The prevalence of syphilis among specific high-risk populations including FSWs is monitored by conducting human immunodeficiency virus (HIV) sentinel surveillance surveys. ${ }^{12}$ The prevalence of syphilis in FSWs varies in different places. . $^{13,14}$

Syphilis is essentially a behavioral related disease and health education has been recognized worldwide as an effective measure to control its spread. ${ }^{15-17}$ Lack of knowledge about precautions and high rates of risk behavior are major factors contributing to the expanding epidemic. ${ }^{18}$ During the Cultural Revolution in China (1966-1976), STIs were so uncommon that they were removed from standard Chinese medical training curricula. ${ }^{19}$ In addition to vaccination and treatment-based strategies for STIs, continued and effective health education and behavioral intervention strategies can reduce the incidence of unprotected sex. However, continuing cross-sectional studies focusing on syphilis are rare in China and data on low-grade FSWs who solicit clients on the street are limited.

In this study, through the analysis of six cross-sectional studies conducted from the same county, we investigated the relationship between awareness of syphilis, risk behaviors and syphilis prevalence in 2482 subjects, aiming to find the prevalence of syphilis in FSWs in different soliciting venues, and identified predictors of infection risk among FSWs.

\section{Methods}

\section{Study Setting and Sample}

Tongxiang, located in eastern China, has approximately 0.8 million residents and a relatively high rate of immigration. ${ }^{20}$ Tongxiang has a highly developed economy and FSWs are active in various different venues in the main urban areas.

\section{Participants and Public Involvement}

Using a convenient sampling strategy, about 400 subjects soliciting in various venues were enrolled into the study between March and June of each year from 2014 to 2019; in total, 2482 participants were enrolled. To be eligible for the study, participants had to meet the following requirements: 1 ) age $\geq 16$ years; 2) self-reported participation in sex work within the last 3 months; and 3) consent to have their blood tested for syphilis.
We developed a unified protocol and all surveyors received strict training. To ensure the reliability of the research data, the owners or managers of the selected entertainment venues were also invited to participate in the training.

After receiving training from staff members of Zhejiang University and Tongxiang Center for Disease Control and Prevention, field staff completed the sample recruitment, face to face anonymous investigation and blood sampling according to the unified protocol. To protect confidentiality, each subject surveys and collected specimen was assigned a corresponding participant identity number. After provided written informed consent, participants were asked a series of questions regarding to their demographics, interventions undertaken, awareness of syphilis and risk behaviors. Blood samples were collected at the same time. After the data statistics, the results have been disseminated to study participants.

\section{Data Definition}

The participants were divided into four age groups, including $\leq 20,21-25,26-30$ and $>30$ years, respectively. According to service solicited and clients price, the participants were divided into high-grade FSWs (usually in hotels, saunas, nightclubs or karaoke venues) and low-grade FSWs (usually on the street or in other public outdoor places). The Risk behavior level was defined as the usage frequency of condoms for all sex activities in the past month. Knowledge awareness was assessed using an 8-item questionnaire designed by the Chinese CDC. ${ }^{21}$ Giving six of eight correct answers was defined as correct knowledge. Subjects who engaged in peer education were supported to promote healthenhancing change among their peers.

\section{Ethics}

The study was conducted in accordance with the declaration of Helsinki, the ethical approval for the study was granted by the Ethics Committee of The First Affiliated Hospital at the School of Medicine of Zhejiang University, and the Ethics Committee approved participants under the age of 18 providing informed consent on their own behalf. The objectives, potential risks and benefits of the study were provided to potential participants during recruitment. All the participants completed the consent statement before the study by themself. Those who were confirmed to have syphilis were enrolled in a syphilis follow-up management system and a cohort study. 


\section{Blood Test}

Serum specimens were tested for syphilis with a rapid plasma reagin (RPR) test (Rongsheng Biotech Company, Shanghai, China). Positive samples on the RPR test underwent Treponema pallidum particle assay (TPPA) (Livzon Inc., Zhuhai, China). Participants with positive results on both the RPR test and the TPPA were considered as syphilis.

\section{Data Analysis}

All data collected by paper-and-pencil surveys were input manually into a custom-designed database and analyzed using SPSS for Windows Version 16.0. Descriptive statistics were generated for each of the general characteristics variables. We used chi-square tests to compare prevalence among different demographic groups. Logistic regression analysis was performed to test risk factors associated with syphilis. All statistical tests were two-sided with a significance level of 0.05 .

\section{Results}

\section{Demographic Characteristics of Participants}

2482 FSWs were enrolled in the study, the number of people included each year was 407, 403, 403, 426, 440 and 403 , respectively. 1307 participants $(52.66 \%)$ were categorized as high-grade FSWs and $1175(47.34 \%)$ as low-grade FSWs. Most of them were single (41.46\%) and married (46.58\%), and only $8.86 \%$ of them received high school education or above, seeing Table 1.

Among the high-grade FSWs, the most common age group was $21-25$ years (37.26\%) and $46.29 \%$ of them were unmarried. The most common age group among the low-grade FSWs was $>30$ years and $53.96 \%$ were single. Most participants had completed junior school education (61.28\% and 55.4\% for high- and low-grade, respectively).

\section{Intervention, Syphilis Awareness, Behavioral Characteristics and Cross-Analysis}

Totally, $43.67 \%$ of them have received free condoms, $76.15 \%$ of which were engaged in peer education. Receipt of free condoms in high-grade FSWs (48.43\%) was significantly higher than that in low-grade FSWs $(38.55 \%)(p<0.001)$, while awareness of syphilis in highgrade FSWs $(87.99 \%)$ was significantly lower than that in low-grade FSWs $(91.91 \%)(p=0.001)$.
The percentage of FSWs received free condoms and engaged in peer education increased significantly over the study period (from $46.44 \%$ to $56.08 \%$ and $7.13 \%$ to $37.47 \%$, respectively, $p<0.05$ ). Awareness of syphilis and the percentage of FSWs having protected sex also increased significantly ( $82.06 \%$ to $89.33 \%$ and $43.73 \%$ to $49.38 \%$, respectively, $p<0.05$, Table 2 ).

\section{Syphilis Prevalence of Participants}

Of the 2482 FSWs samples tested for syphilis, 107 (4.31\%) were positive. The prevalence of syphilis in high-grade FSWs was significantly lower than that in low-grade FSWs (3.14\% vs $5.62 \%)$. Different marital status showed significant differences in prevalence of syphilis among all participants $(p=$ $0.002)$. This trend could also be found in high- and low-grade FSWs people $(p=0.034, p=0.025)$ with the highest level in divorced and widowed status. Also, the prevalence of syphilis was related to the education level. Higher education level may result with lower prevalence $(p=0.011)$, and the same significant trend can be seen in high-grade FSWs $(p=0.02)$. And this level also increased with the upgrade of age, but there was no significant difference can be observed, seeing Table 3 .

The overall prevalence of syphilis increased from 3.19\% to $4.47 \%$ (Table 2) from 2014 to 2019 . The prevalence in highgrade FSWs declined from $2.95 \%$ to $1.32 \%$, whereas in lowgrade FSWs it increased from $3.92 \%$ to $6.35 \%$, which was responsible for the observed overall increase. The prevalence of syphilis in high-grade FSWs was significantly lower than that in low-grade FSWs in 2018 and $2019(p<0.05$, Figure 1). The results showed that the prevalence of syphilis in participants who received condom was significantly lower than those without receiving condom $(p=0.031)$.

\section{Risk Associations}

Univariate analysis of syphilis-related risk factors showed that, compared with high-grade FSWs, syphilis risk level was greater in low-grade FSWs (odds ratio $(\mathrm{OR})=1.76,95 \% \mathrm{CI}$ $1.18-2.63, p<0.05)$. Compared with those under divorced and widowed status, the single, married and cohabiting FSWs were at lower risk of syphilis $(\mathrm{OR}=0.29,95 \% \mathrm{CI} 0.13-0.62$, $p=0.001 ; \mathrm{OR}=0.29,95 \%$ CI $0.19-0.84, p=0.015 ; \mathrm{OR}=0.2$, $95 \%$ CI $0.06-0.61, p=0.005$; respectively). Similiar results can be seen in low-grade FSWs. For high-grade FSWs, compared with the high school or above education group, syphilis risk was higher for those receiving primary school or below and punior school education (OR $=4.39,95 \%$ CI 1.01-19.15, $p=0.049 ; \mathrm{OR}=2.1,95 \% \mathrm{CI} 0.49-9.02, p=0.321$; respectively Table 4). 
Table I Demographics of Female Sex Workers (FSWs) in Six Consecutive Cross-Sectional Surveys

\begin{tabular}{|c|c|c|c|c|}
\hline & & $\begin{array}{c}\text { All FSWs } \\
\text { n (\%) }\end{array}$ & $\begin{array}{c}\text { High-Grade FSWs } \\
\text { n (\%) }\end{array}$ & $\begin{array}{c}\text { Low-Grade FSWs } \\
\text { n (\%) }\end{array}$ \\
\hline Venues & $\begin{array}{l}\text { High-grade places } \\
\text { Low-grade places }\end{array}$ & $\begin{array}{l}1307(52.66) \\
1175(47.34)\end{array}$ & & \\
\hline Age (years) & $\begin{array}{l}\leqq 20 \\
21 \sim 25 \\
26 \sim 30 \\
>30\end{array}$ & $\begin{array}{l}653(26.31) \\
744(29.98) \\
479(19.30) \\
606(24.42)\end{array}$ & $\begin{array}{l}343(26.24) \\
487(37.26) \\
268(20.5) \\
209(15.99)\end{array}$ & $\begin{array}{l}310(26.38) \\
257(21.87) \\
211(17.96) \\
397(33.79)\end{array}$ \\
\hline Marital status & $\begin{array}{l}\text { Single } \\
\text { Married } \\
\text { Cohabiting } \\
\text { Divorced \& widowed }\end{array}$ & $\begin{array}{l}1029(41.46) \\
1156(46.58) \\
216(8.70) \\
81(3.26)\end{array}$ & $\begin{array}{l}605(46.29) \\
522(39.94) \\
135(10.33) \\
45(3.44)\end{array}$ & $\begin{array}{l}424(36.09) \\
634(53.96) \\
81(6.89) \\
36(3.06)\end{array}$ \\
\hline Education & $\begin{array}{l}\text { Primary school or below } \\
\text { Junior school } \\
\text { High school or above }\end{array}$ & $\begin{array}{l}803(32.35) \\
\mid 459(58.78) \\
220(8.86)\end{array}$ & $\begin{array}{l}340(26.01) \\
808(61.82) \\
159(12.17)\end{array}$ & $\begin{array}{l}463(39.4) \\
65 I(55.4) \\
6 I(5.19)\end{array}$ \\
\hline Receipt of free condoms & $\begin{array}{l}\text { Yes } \\
\text { No }\end{array}$ & $\begin{array}{l}1086(43.76) \\
1396(56.24)\end{array}$ & $\begin{array}{l}633(48.43) \\
674(51.57)\end{array}$ & $\begin{array}{l}453(38.55) \\
722(61.45)\end{array}$ \\
\hline Peer education & $\begin{array}{l}\text { Yes } \\
\text { No }\end{array}$ & $\begin{array}{l}1890(76.15) \\
592(23.85)\end{array}$ & $\begin{array}{l}985(75.36) \\
322(24.64)\end{array}$ & $\begin{array}{l}905(77.02) \\
270(22.98)\end{array}$ \\
\hline Risk behaviors & $\begin{array}{l}\text { Yes } \\
\text { No }\end{array}$ & $\begin{array}{l}1177(47.42) \\
1305(52.58)\end{array}$ & $\begin{array}{l}622(47.59) \\
685(52.4 I)\end{array}$ & $\begin{array}{l}555(47.23) \\
620(52.77)\end{array}$ \\
\hline Knowledge awareness & $\begin{array}{l}\text { Yes } \\
\text { No }\end{array}$ & $\begin{array}{l}2230(89.85) \\
252(10.15)\end{array}$ & $\begin{array}{l}\text { II50(87.99) } \\
157(12.01)\end{array}$ & $\begin{array}{l}1080(91.91) \\
95(8.09)\end{array}$ \\
\hline Syphilis & $\begin{array}{l}\text { Positive } \\
\text { Negative }\end{array}$ & $\begin{array}{l}107(4.31) \\
2375(95.69)\end{array}$ & $\begin{array}{l}4 \mid(3.14) \\
1266(96.86)\end{array}$ & $\begin{array}{l}66(5.62) \\
1109(94.38)\end{array}$ \\
\hline
\end{tabular}

Table 2 Knowledge, Behavioral, Intervention and Serological Characteristics of Female Sex Workers in Six Consecutive CrossSectional Surveys

\begin{tabular}{|c|c|c|c|c|c|c|c|c|}
\hline & $\begin{array}{c}2014 \\
(N=407) \\
n(\%)\end{array}$ & $\begin{array}{c}2015 \\
(N=403) \\
n(\%)\end{array}$ & $\begin{array}{c}2016 \\
(N=403) \\
n(\%)\end{array}$ & $\begin{array}{c}2017 \\
(N=426) \\
n(\%)\end{array}$ & $\begin{array}{c}2018 \\
(N=440) \\
n(\%)\end{array}$ & $\begin{array}{c}2019 \\
(N=403) \\
n(\%)\end{array}$ & $p$ value* & $\begin{array}{l}p \text { value for } \\
\text { Trend ** }\end{array}$ \\
\hline Receipt of free condoms & 189(46.44) & $200(49.63)$ & $219(54.34)$ & $274(64.32)$ & $288(65.45)$ & $226(56.08)$ & $<0.01$ & $<0.01$ \\
\hline Peer education & $29(7.13)$ & $84(20.84)$ & $105(26.05)$ & $89(20.89)$ & $134(30.45)$ & $151(37.47)$ & $<0.01$ & $<0.01$ \\
\hline Knowledge awareness & $334(82.06)$ & $353(87.59)$ & $370(91.81)$ & $396(92.96)$ & $417(94.77)$ & $360(89.33)$ & $<0.01$ & $<0.01$ \\
\hline Risk behaviors & I78(43.73) & $237(58.81)$ & $222(55.09)$ & $218(51.17)$ & $25 I(57.05)$ & $199(49.38)$ & $<0.01$ & 0.326 \\
\hline Syphilis & $13(3.19)$ & $15(3.72)$ & 14(3.47) & $27(6.34)$ & $20(4.55)$ & $18(4.47)$ & 0.254 & 0.162 \\
\hline
\end{tabular}

Notes: *By Chi-square test. **Linear-by-linear association analysis by Chi-square test.

\section{Discussion}

In the present study, the prevalence of syphilis was $4.31 \%$, which is consistent with that in Yunnan but lower than that in Xichang and Shandong Province $(15.7 \%$ and $7.4 \%$, respectively). ${ }^{22-26}$ The prevalence varied significantly between FSW grade, being 3.14\% in high-grade FSWs and $5.62 \%$ in low-grade FSWs. Previous studies have found extremely high prevalence of syphilis in low-grade FSWs, ranging from $10 \%$ to $38 \% .{ }^{27,28}$ FSWs working in low-grade venues tend to have a greater number of clients, but infrequently use condoms due to extra payments for unsafe sex; ${ }^{29}$ furthermore, low-grade FSWs independently solicit clients either on streets or at construction sites and factories ${ }^{29}$ and more frequently vary their working locations. ${ }^{29-31}$ From the 
Table 3 Comparison of Demographic and Behavioral Characteristics of Syphilis Positive and Syphilis Negative Female Sex Workers

\begin{tabular}{|c|c|c|c|c|c|c|c|}
\hline & & \multicolumn{2}{|c|}{ All FSWs } & \multicolumn{2}{|c|}{ High-Grade FSWs } & \multicolumn{2}{|c|}{ Low-Grade FSWs } \\
\hline & & $\begin{array}{l}\text { Syphilis Positive } \\
\text { (N=107) } \\
\text { n(Prevalence \%) }\end{array}$ & $p$ value & $\begin{array}{l}\text { Syphilis Positive } \\
(\mathbf{N}=41) \\
\text { n(Prevalence \%) }\end{array}$ & $p$ value & $\begin{array}{l}\text { Syphilis Positive } \\
(\mathrm{N}=66) \\
\text { n(Prevalence \%) }\end{array}$ & $p$ value \\
\hline Age (years) & $\begin{array}{l}\leqq 20 \\
21 \sim 25 \\
26 \sim 30 \\
>30\end{array}$ & $\begin{array}{l}22(3.37) \\
26(3.49) \\
22(4.59) \\
37(6.11)\end{array}$ & 0.059 & $\begin{array}{l}8(2.33) \\
12(2.46) \\
10(3.73) \\
11(5.26)\end{array}$ & 0.181 & $\begin{array}{l}14(4.52) \\
14(5.45) \\
12(5.69) \\
26(6.55)\end{array}$ & 0.711 \\
\hline Marital status & $\begin{array}{c}\text { Single } \\
\text { Married } \\
\text { Cohabiting } \\
\text { Divorced\&widowed }\end{array}$ & $\begin{array}{l}35(3.40) \\
58(5.02) \\
5(2.31) \\
9(11.11)\end{array}$ & 0.002 & $\begin{array}{l}16(2.64) \\
22(4.21) \\
0(0.00) \\
3(6.67)\end{array}$ & 0.034 & $\begin{array}{l}19(4.48) \\
36(5.68) \\
5(6.17) \\
6(16.67)\end{array}$ & 0.025 \\
\hline Education & $\begin{array}{c}\text { Primary school or } \\
\text { below } \\
\text { Junior school } \\
\text { High school or above }\end{array}$ & $\begin{array}{l}48(5.98) \\
54(3.70) \\
5(2.27)\end{array}$ & 0.011 & $\begin{array}{l}18(5.29) \\
21(2.60) \\
2(1.26)\end{array}$ & 0.02 & $\begin{array}{l}30(6.48) \\
33(5.07) \\
3(4.92)\end{array}$ & 0.584 \\
\hline $\begin{array}{l}\text { Receipt of free } \\
\text { condoms }\end{array}$ & $\begin{array}{l}\text { Yes } \\
\text { No }\end{array}$ & $\begin{array}{l}36(3.31) \\
7 I(5.09)\end{array}$ & 0.031 & $\begin{array}{l}15(2.37) \\
26(3.86)\end{array}$ & 0.123 & $\begin{array}{l}21(4.64) \\
45(6.23)\end{array}$ & 0.247 \\
\hline Peer education & $\begin{array}{l}\text { Yes } \\
\text { No }\end{array}$ & $\begin{array}{l}75(3.97) \\
32(5.4 I)\end{array}$ & 0.133 & $\begin{array}{l}30(3.05) \\
I I(3.42)\end{array}$ & $0.74 I$ & $\begin{array}{l}45(4.97) \\
21(7.78)\end{array}$ & 0.079 \\
\hline Risk behaviors & $\begin{array}{l}\text { Yes } \\
\text { No }\end{array}$ & $\begin{array}{l}56(4.76) \\
51(3.91)\end{array}$ & 0.298 & $\begin{array}{l}20(3.22) \\
21(3.07)\end{array}$ & 0.877 & $\begin{array}{l}36(6.49) \\
30(4.84)\end{array}$ & 0.221 \\
\hline $\begin{array}{l}\text { Knowledge } \\
\text { awareness }\end{array}$ & $\begin{array}{l}\text { Yes } \\
\text { No }\end{array}$ & $\begin{array}{l}92(4.13) \\
15(5.95)\end{array}$ & 0.176 & $\begin{array}{l}34(2.96) \\
7(4.46)\end{array}$ & 0.311 & $\begin{array}{l}58(5.37) \\
8(8.42)\end{array}$ & 0.216 \\
\hline
\end{tabular}

analysis of six independent samples, we found that the prevalence of syphilis was $3.19 \%$ to $4.47 \%$ and exhibited an increasing trend over the study period with no significant difference. The increase in overall prevalence was mainly due to the increase values among low-grade FSWs (from $3.92 \%$ to $6.35 \%$ ); while the prevalence in the high-grade FSWs decreased.

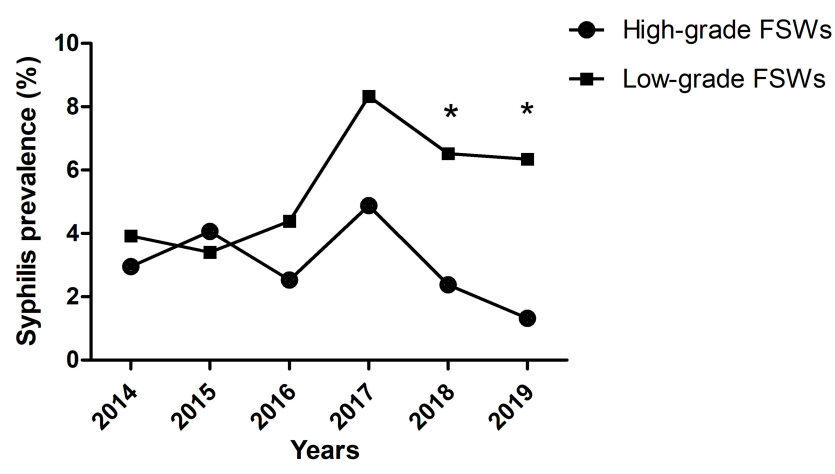

Figure I Syphilis prevalence in female sex workers (FSWs) from 2014 to 2019. Note: *Significant difference $(p<0.05)$ between high- and low-grade FSWs.
Risk behaviors and socio-demographic characteristics of FSWs linked to the sex trade may be associated with risk of syphilis and other STIs. ${ }^{32,33}$ In our study, we found that distribution of free condoms and peer education may increase syphilis awareness and reduce high-risk behavior, but these interventions did not reduce the prevalence of syphilis. Cross-analysis showed that preventive measures can affect both cognitive and behavioral factors $(p<0.05)$, but the rate of infection was not significantly reduced $(p>$ 0.05 ), especially in low-grade FSWs. In the low-grade FSWs group, the receipt of free condoms and awareness of syphilis were greater but there was a significant increase in the prevalence of syphilis. From the results of this study, we can assume that subjective cognitive measures do not accurately reflect behaviors. In addition, awareness of the benefits of condom use for the reduction of STI acquisition may not be the determinant for use of condoms. Observational studies have reported that the presence of syphilis and herpes simplex virus 2 infection increased the risk of HIV acquisition 2-3-fold. ${ }^{34-36}$ 
Table 4 Odds Ratios (OR) and 95 Confidence Intervals $(\mathrm{Cl})$ of Syphilis Among All Female Sex Workers (FSWs) and According to Location of Venues

\begin{tabular}{|c|c|c|c|c|c|c|c|}
\hline \multicolumn{2}{|l|}{ Items } & \multicolumn{2}{|c|}{ All FSWs } & \multicolumn{2}{|c|}{ High-Grade FSWs } & \multicolumn{2}{|c|}{ Low-Grade FSWs } \\
\hline & & OR(95\% Cl) & $p$ value & OR(95\% Cl) & $p$ value & OR(95\% Cl) & $p$ value \\
\hline Venues & $\begin{array}{l}\text { High-grade places } \\
\text { Low-grade places }\end{array}$ & $\begin{array}{c}\text { Ref } \\
1.76(1.18-2.63)\end{array}$ & 0.006 & - & & - & \\
\hline Marital status & $\begin{array}{c}\text { Single } \\
\text { Married } \\
\text { Cohabiting } \\
\text { Divorced \& widowed }\end{array}$ & $\begin{array}{l}0.29(0.13-0.62) \\
0.4(0.19-0.84) \\
0.2(0.06-0.61) \\
\text { Ref }\end{array}$ & $\begin{array}{l}0.001 \\
0.015 \\
0.005\end{array}$ & - & & $\begin{array}{c}0.24(0.09-0.63) \\
0.3(0.12-0.77) \\
0.33(0.09-1.16) \\
\text { Ref }\end{array}$ & $\begin{array}{l}0.004 \\
0.012 \\
0.084\end{array}$ \\
\hline Education & $\begin{array}{c}\text { Primary school or below } \\
\text { Junior school } \\
\text { High school and above }\end{array}$ & - & & $\begin{array}{c}4.39(1.01-19.15) \\
2.1(0.49-9.02) \\
\operatorname{Ref}\end{array}$ & $\begin{array}{l}0.049 \\
0.321\end{array}$ & - & \\
\hline
\end{tabular}

Notes: The following potential risk factors were in the full model: venues, age, marital status, education, receipt of free condoms, peer education, knowledge awareness, risk behaviors. Odds ratios and 95 confidence intervals adjusted for the potential risk factors that were statistically significant in the three different logistic models. Abbreviations: $\mathrm{OR}$, odds ratio; $\mathrm{Cl}$, confidence interval.

In the present study, regression analysis showed that low-grade FSWs had a high risk of syphilis. A 2006 national survey among men aged 15-49 years indicated that $4.2 \%$ had visited FSWs in the previous year. This proportion was $7.2 \%$ in urban areas and $1.8 \%$ in rural areas, and observations in several areas have suggested that the clients of low-grade FSWs are usually migrants and elder men. ${ }^{37}$ Lower education level was also identified as a risk factor for syphilis in our multivariate model. FSWs with poor education may have less access to the information about STIs, knowledge about prevention, safesex practices and health-seeking behaviors.

Overall, the study has the following limitations: firstly, some of the data collected were based on self-reports, which made it difficult to obtain accurate information about sexual behavior despite guaranteed anonymity, leading to a possible reporting bias; secondly, using the rapid plasma reagin (RPR) test as the first step may cause falsenegative results due to the prozone phenomenon; finally, the cross-sectional nature of the study placed obstacles on determining a causal relationship.

\section{Conclusion}

In conclusion, through continuing syphilis prevention and control strategies in recent years, the prevalence of syphilis has been maintained at a low level with a slightly increasing trend, mainly due to an increase level among low-grade FSWs. Due to the "separation of knowledge and behavior" that we have observed, syphilis did not decline despite the increase of preventive measures and behavioral changes, especially in low-grade FSWs. More effective integrated interventions should be developed, especially for high-risk populations such as low-grade, elder, divorced and widowed FSWs.

\section{Data Sharing Statement}

The authors are willing to share the entire individual participant data collected during the study, after de-identification. These data will be available beginning 3 months and ending 5 years after article publication. Requests should be directed to tianshengxie@126.com. To gain access, data requestors are needed to sign a data access agreement.

\section{Acknowledgments}

Authors would like to thank prof. Nanping Wu for his kind guidance in study design, and Mrs. Jingwen Xue for the help in language polishing for this publication. Also, thank the Bureau of Health of Tongxiang county and the Prevention and Treatment Working Group of HIV/AIDS in Zhejiang Major Infectious District for their supporting organizations that helped with recruitment.

\section{Funding}

This study was supported by the National Natural Science Foundation of China (No.81602943), the Medical and Health Science and Technology Project of Zhejiang(2014KYA243), and the Mega-Project for National Science and Technology Development (2017ZX10105001). The funders had no role in study design, data collection and analysis, decision to publish, or preparation of the manuscript.

\section{Disclosure}

The authors report no conflicts of interest in this work. 


\section{References}

1. World Health Organization, Department of Reproductive Health and Research. The Global Elimination of Congenital Syphilis: rationale and Strategy for Action; 2007. Available from: https://www.who.int/ reproductivehealth/publications/rtis/9789241595858/en/. Accessed April 2, 2021.

2. World Health Organization. Global Health Sector Strategy on Sexually Transmitted Infections, 2016-2021. World Health Organization; 2016.

3. Korenromp EL, Wi T, Resch S, Stover J, Broutet N. Costing of National STI Program Implementation for the Global STI Control Strategy for the Health Sector, 2016-2021. PLoS One. 2017;12(1): e0170773. doi:10.1371/journal.pone.0170773

4. Korenromp EL, Mahiané SG, Nagelkerke N, et al. Syphilis prevalence trends in adult women in 132 countries - estimations using the Spectrum Sexually Transmitted Infections model. Sci Rep. 2018;8 (1):11503. doi:10.1038/s41598-018-29805-9

5. National Center for AIDS/STD Control and Prevention China CDC. China syphilis control plan (2010-2020) - interim assessment guideline; 2010. Available from: http://www.nhc.gov.cn/zwgk/wtwj/ 201304/bb67c7a0e7c140d7b5ad25ca5106b659.shtml. Accessed March 21, 2021.

6. Galvin SR, Cohen MS. The role of sexually transmitted diseases in HIV transmission. Nat Rev Microbiol. 2004;2(1):33-42. doi:10.1038/ nrmicro794

7. Yang S, Wu J, Ding C, et al. Epidemiological features of and changes in incidence of infectious diseases in China in the first decade after the SARS outbreak: an observational trend study. Lancet Infect Dis. 2017;17(7):716-725. doi:10.1016/S1473-3099(17)30227-X

8. Pirkle C, Soundardjee R, Stella A. Female sex workers in China: vectors of disease? Sex Transm Dis. 2007;34(9):695-703. doi:10.1097/01.olq.0000260989.70866.94

9. Yang H, Li X, Stanton B, et al. Condom use among female sex workers in China: role of gatekeepers. Sex Transm Dis. 2005;32 (9):572-580. doi:10.1097/01.olq.0000175418.48665.95

10. 2015 China AIDS Response Progress Report. National Health and Family Planning Commission of the People's Republic of China; 2015. Available from: http://www.unaids.org/sites/default/files/coun try/documents/CHN_narrative_report_2015.pdf. Accessed March 21, 2021.

11. Poon AN, Li Z, Wang N, Hong Y. Review of HIV and other sexually transmitted infections among female sex workers in China. AIDS Care. 2011;23(Suppl 1):5-25. doi:10.1080/09540121.2011.554519

12. Tucker JD, Cohen MS. China's syphilis epidemic: epidemiology, proximate determinants of spread, and control responses. Curr Opin Infect Dis. 2011;24(1):50-55. doi:10.1097/QCO.0b013e32834204bf

13. Gil VE, Wang MS, Anderson AF, Lin GM, Wu ZO. Prostitutes, prostitution and STD/HIV transmission in mainland China. Soc Sci Med. 1996;42(1):141-152. doi:10.1016/0277-9536(95)00064-x

14. Lin CC, Gao X, Chen X-S, Chen Q, Cohen MS. China's syphilis epidemic: a systematic review of seroprevalence studies. Sex Transm Dis. 2006;33(12):726-736. doi:10.1097/01.olq.0000222703.12018.58

15. Powers KA, Poole C, Pettifor AE, Cohen MS. Rethinking the heterosexual infectivity of HIV-1: a systematic review and meta-analysis. Lancet Infect Dis. 2008;8(9):553-563. doi:10.1016/S1473-3099(08) 70156-7

16. Jain AK, Saggurti N, Mahapatra B, et al. Relationship between reported prior condom use and current self-perceived risk of acquiring HIV among mobile female sex workers in southern India. BMC Public Health. 2011;11(Suppl 6):S5. doi:10.1186/ 1471-2458-11-S6-S5

17. Huang Y, Maman S, Pan S. Understanding the diversity of male clients of sex workers in China and the implications for HIV prevention programmes. Glob Public Health. 2012;7(5):509-521. doi:10.1080/17441692.2012.657663
18. Vuylsteke B, Semdé G, Sika L, et al. HIV and STI prevalence among female sex workers in Côte d'Ivoire: why targeted prevention programs should be continued and strengthened. PLoS One. 2012;7(3): e32627. doi:10.1371/journal.pone.0032627

19. Cohen MS, Henderson GE, Aiello P, Zheng H. Successful eradication of sexually transmitted diseases in the People's Republic of China: implications for the 21st century. J Infect Dis. 1996;174 Suppl 2: S223-S229. doi:10.1093/infdis/174.supplement_2.s223

20. Zhejiang Provincial Bureau of Statistics. Zhejiang Statistical Yearbook2020. China Statistics Press; 2020.

21. The State Council AIDS Working Committee Office. China HIV/ AIDS Monitoring and Evaluation Framework (Trial). Beijing Medical Publishing House; 2007.

22. Chen Z-Q, Zhang G-C, Gong X-D, et al. Syphilis in China: results of a national surveillance programme. Lancet. 2007;369 (9556):132-138. doi:10.1016/S0140-6736(07)60074-9

23. Wang HB, Smith K, Brown KS, et al. Prevalence, incidence, and persistence of syphilis infection in female sex workers in a Chinese province. Epidemiol Infect. 2011;139(9):1401-1409. doi:10.1017/ S0950268810002578

24. Ruan Y, Cao X, Qian H-Z, et al. Syphilis among female sex workers in southwestern China: potential for HIV transmission. Sex Transm Dis. 2006;33(12):719-723. doi:10.1097/01.olq.0000218881.01437.99

25. Ruan Y, Luo F, Jia Y, et al. Risk factors for syphilis and prevalence of HIV, hepatitis B and C among men who have sex with men in Beijing, China: implications for HIV prevention. AIDS Behav. 2009;13(4):663-670. doi:10.1007/s10461-008-9503-0

26. Wang B, Li X, Stanton B, et al. Vaginal douching, condom use, and sexually transmitted infections among Chinese female sex workers. Sex Transm Dis. 2005;32(11):696-702. doi:10.1097/01.olq.0000175403.68410.ec

27. Wang -Q-Q, Chen X-S, Yin Y-P, et al. HIV/STD pattern and its associated risk factors among male STD clinic attendees in China: a foci for HIV intervention. BMC Public Health. 2011;11(1):955. doi:10.1186/1471-2458-11-955

28. Yang P, Wang Q. A survey of syphilis and HIV infection in medium-low income female sex workers. China J Lepr Skin Dis. 2009;25:174-176. doi:10.3969/j.issn.1009-1157.2009.03.007

29. Yang X, Xia G, Li X, Latkin C, Celentano D. Social influence and individual risk factors of HIV unsafe sex among female entertainment workers in China. AIDS Educ Prev. 2010;22(1):69-86. doi:10.1521/ aeap.2010.22.1.69

30. Huang Y, Henderson GE, Pan S, Cohen MS. HIV/AIDS risk among brothel-based female sex workers in China: assessing the terms, content, and knowledge of sex work. Sex Transm Dis. 2004;31 (11):695-700. doi:10.1097/01.olq.0000143107.06988.ea

31. Yang C, Latkin C, Luan R, Wang C, Nelson K. HIV, syphilis, hepatitis $\mathrm{C}$ and risk behaviours among commercial sex male clients in Sichuan province, China. Sex Transm Infect. 2010;86(7):559-564. doi:10.1136/sti.2009.041731

32. Choi KH, Zheng X, Zhou H, Chen W, Mandel J. Treatment delay and reliance on private physicians among patients with sexually transmitted diseases in China. Int J STD AIDS. 1999;10(5):309-315. doi:10.1258/0956462991914177

33. Shannon K, Strathdee SA, Shoveller J, Rusch M, Kerr T, Tyndall MW. Structural and environmental barriers to condom use negotiation with clients among female sex workers: implications for HIV-prevention strategies and policy. Am J Public Health. 2009;99 (4):659-665. doi:10.2105/AJPH.2007.129858

34. Swain SN, Saggurti N, Battala M, Verma RK, Jain AK. Experience of violence and adverse reproductive health outcomes, HIV risks among mobile female sex workers in India. BMC Public Health. 2011;11 (1):357. doi:10.1186/1471-2458-11-357

35. Barnabas RV, Wasserheit JN, Huang Y, et al. Impact of herpes simplex virus type 2 on HIV-1 acquisition and progression in an HIV vaccine trial (the Step study). J Acquir Immune Defic Syndr. 2011;57(3):238-244. doi:10.1097/QAI.0b013e31821acb5 
36. Ruzagira E, Wandiembe S, Abaasa A, et al. HIV incidence and risk factors for acquisition in HIV discordant couples in Masaka, Uganda: an HIV vaccine preparedness study. PLoS One. 2011;6(8):e24037. doi:10.1371/journal.pone. 0024037
37. Lu F, Wang N, Wu Z, et al. Estimating the number of people at risk for and living with HIV in China in 2005: methods and results. Sex Transm Infect. 2006;82 Suppl 3:iii87-iii91. doi:10.1136/sti.2006. 020404

\section{Publish your work in this journal}

The Journal of Multidisciplinary Healthcare is an international, peerreviewed open-access journal that aims to represent and publish research in healthcare areas delivered by practitioners of different disciplines. This includes studies and reviews conducted by multidisciplinary teams as well as research which evaluates the results or conduct of such teams or healthcare processes in general. The journal covers a very wide range of areas and welcomes submissions from practitioners at all levels, from all over the world. The manuscript management system is completely online and includes a very quick and fair peer-review system. Visit http://www.dovepress.com/testimonials. php to read real quotes from published authors. 